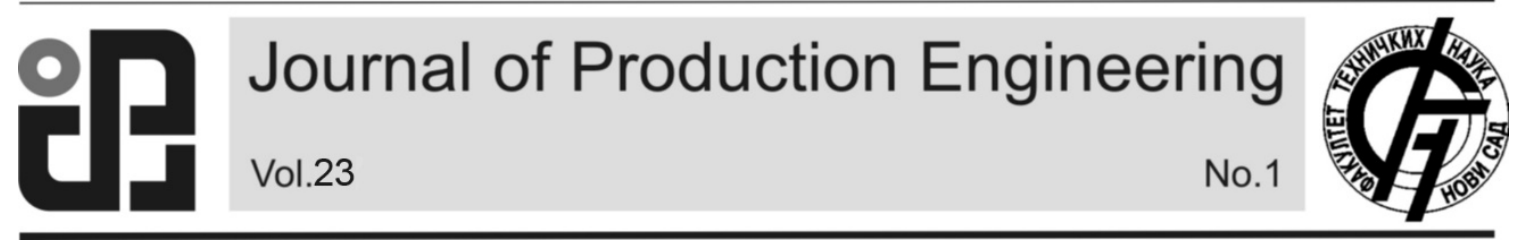

JPE (2020) Vol.23 (1)

Erdei L., Illés. B., Tamás, P.

Original Scientific Paper

\title{
ANALYSIS OF TRAIN CONTROL SYSTEM STANDARDIZATION
}

\author{
Received: 08 April 2020 / Accepted: 21 June 2020
}

Abstract: The volume of purchased goods from the Far Eastern market is increasing year by year. In addition to delivering increasing quantities of goods, efforts should be made to reduce delivery times. The railway transportation is an optimal solution to this problem. The competitiveness of rail transport can be increased by using intelligent train control systems. The European Train Control System (ETCS) is a modern train control system. In this work the authors are presenting a new ETCS level with some new intelligent solutions for decrease delivery times.

Key words: Modern Silk Road, railway transport, ETCS, development, intelligent solutions.

Analiza standardizacije sistema za upravljanja vozom. Obim kupljene robe sa tržišta Dalekog Istoka iz godine u godinu se povećava. Pored isporuke sve većih količina robe, potrebno je uložiti napore i za skraćenje roka isporuke. Železnički prevoz je optimalno rešenje ovog problema. Konkurentnost železničkog saobraćaja može se povećati korišćenjem inteligentnih sistema za upravljanje vozom. Evropski sistem upravljanja vozom (ETCS) moderan je sistem za upravljanje vozom. U ovom radu autori predstavljaju novi nivo ETCS-a sa nekim novim inteligentnim rešenjima za smanjenje rokova isporuke.

Ključne reči: Savremeni put svile, železnički saobraćaj, ETCS, razvoj, inteligentna rešenja.

\section{INTRODUCTION}

In the world, e-commerce is generating increasing traffic every year, because people tend to do the shopping from online stores (Wish, eBay, etc.), which is becoming more popular year after year [1]. The vendors offer free shipping charges, which means more competitive prices to the customers, but this comes with disadvantages like lost packages and high delivery times. The cheap or even free shipping is available by maritime transport, so rail transport could be a good alternative in the future to shorten long transport times.

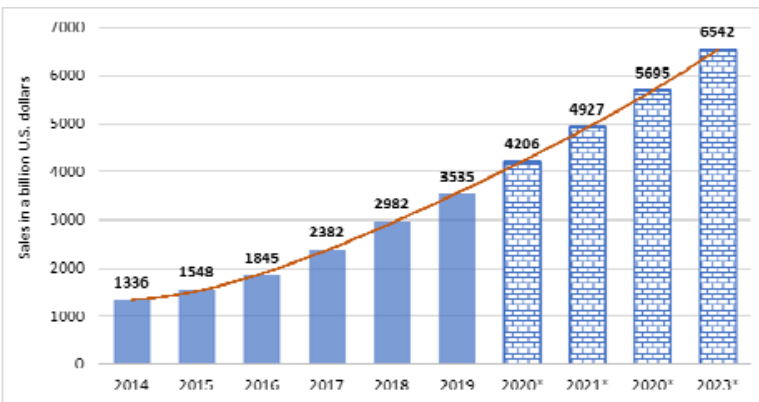

Fig. 1. Retail e-commerce sales worldwide from 2014 to 2019 and prognosis to 2023 with polynomial trendline [2]

Trade in goods between the Far East and Europe will increase year by year. (Fig. 1.) The rise of rail transport is well-founded, as it is faster transport than by maritime and also cheaper than faster air freight. The new concept is the modern Silk Road [3].

Hungary is a central located country in Europe, so many major European transport routes cross this country. Railways are an integral part of these networks
(Helsinki corridor) [4]. Rail transport has become one of the safest form of transport through the use of more modern safety devices and train control systems. However, simplification and standardization have not been resolved completely in these systems yet. Therefore, the following is an examination of competitive train control systems, followed by a theory of a modern, simple and safe train control system that can bring benefits for rail freight and passenger transport.

From the middle of the second half of the 19th century, we can speak of actual train controlling as the mechanical system was developed by Axel Vogt. This braking system began to be applied to the Pennsylvania Railroad. Trains were braked via mechanical contact. If a train passed the "Stop!" railway signal, the system mechanically broke the glass tube inserted in the main brake line of the locomotive. Due to the pressure drop, the train suddenly started to brake [5]. The system stopped the vehicle, but expectations of increasing speed and safety also increased over time, so new solutions had to be developed.

Purely mechanical contacts cannot perform complex signal transmission. First electromechanical connection was realized by the "crocodile" system, which has been used in France, Belgium and Luxembourg since the 1870s. England has developed its own train control system as well as the USA. Germany has set up the „Indusi” (PZB) train control system, which is still used in several European and Asian county [5]. There are a few methods for train controlling that can be implemented with different systems and units. In Europe, almost every country uses a different type of train control systems [6][7].

The application of a standardized train control 
system could make a major contribution to increasing the efficiency of international rail transport.

\section{TRAIN CONTROLLING BY ETCS}

ETCS (European Train Control System) created for standard cross-border train control. ETCS seeks to ensure rail safety in almost all areas. It can process information provided by multiple external and internal systems, so it can be stated, that ETCS outranges the average train control systems through its diversified services. ETCS has a modular structure, so it is possible to install the system elements gradually. Therefore, if it is decided to install ETCS on a railway line, there is no need to stop or severely restrict train traffic during the works. The work can begin with determining the location of balises, the GSM-R towers building at appointed stations and installation of transmitter and signal boxes. ETCS consist of trackside and board-side system elements.

\begin{tabular}{|c|c|}
\hline$\frac{\text { Track-side system }}{\text { elements }}$ & $\frac{\text { Board-side system }}{\text { elements }}$ \\
\hline $\begin{array}{c}\text { euro-balise, euro-loop, } \\
\text { railway traffic signal, } \\
\text { RBC, LEU, etc. }\end{array}$ & $\begin{array}{c}\text { STM, data-recorder, } \\
\text { radio, GSM-R antenna, } \\
\text { radar, sensors, etc. }\end{array}$ \\
\hline
\end{tabular}

Table 1. ETCS system elements [7]

High-speed rail traffic requires several safety standards and conditions. The high level of train control represented by ETCS will be needed for highspeed railway. For example, one of the conditions is that instead of using railway barriers (where rail and road cross each other), underpasses or overpasses must be built [8]. The European Train Control System consists of different levels according to the functions performed on the track sections and the transmission of information [7].

Difference among ETCS levels:

- different functions,

- the place of implementation of the functions,

- communication,

- construction and installation costs,

- etc [9].

The following subsystems present the currently standardized levels of ETCS [10].

\subsection{ETCS Level 0}

In addition to the three basic levels, we speak of ETCS Level 0 if:

- a train (equipped with ETCS board-side elements) runs on railway, where ETCS trackside elements are not installed,

- the board-side subsystem is not aligned with the track-side subsystem.

The board-side sensor monitors the speed of train. If the maximum speed is exceeded, the system automatically decelerates the train or turn on the emergency brakes. Overall, ETCS Level 0 is only an additional level to prevent accidents due to "speeding" [6][7].

\subsection{STM module}

The Specific Transmission Module just a module not an ETCS level. The STM module can communicate among different train control systems. It has been developed to eliminate the need for locomotive exchanges at border stations for international passenger and freight transport. Delivery and travel times have been greatly reduced with this solution. For those trains which travel through more than two countries, the locomotive should be equipped with 3 or more train control systems. The STM module has solved this compatibility problem between the train control systems used by different railway companies, with a cheap solution. Due to the modular design, only those modules should be installed which the given countries determining. The STM module receives information (non-ETCS) at its input, and it converts this signal to the ETCS format and transmits it to the central computer and via it to the other units. [6] [8].

\subsection{ETCS Level 1}

ETCS Level 1 functions as a full-fledged system. So it is not just interfering with controls while the train exceeds the speed limit. in the event of speeding that it can interfere with control. First of all, the balise needs to be defined. (Fig. 2.) The balise is an electromagnetic device attached between two pairs of rails. „Balise” is a French word meaning tag and signpost. This is the most basic track-side element. The balise as an electromagnetic structure contains an inactive coil. They are placed at certain distances along the track and on privileged track elements (e.g. at signal poles, barriers).

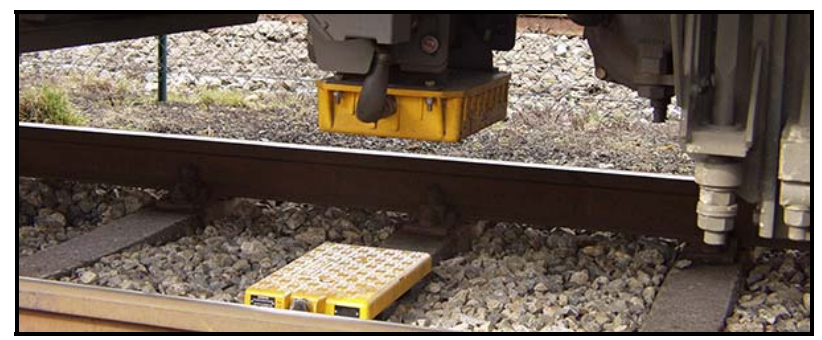

Fig. 2. A balise is placed on the line and a scanner is equipped under the locomotive [11]

The balises create intervals thus point-to-point train control to come into existence. If the sensor passes through a balise, information can be transmitted to the locomotive, which can be used for emergency braking or to control other movements or operations [6][7].

\subsection{ETCS Level 2}

ETCS Level 2 is an improved version of the previous level. Train detection can be done with rail circuits or axle counters. At this level, communication is not happening through balises, but motion data and information, which are transmitted through a wireless communication system. This system is a GSM-R communication system that implements two-way data movement between radio block centers and locomotives. The Radio Block Center (RBC) is a control center with complex functions. The RBCs usually built at major train stations. The RBC monitors 
fixed track-side elements, and the movement and position of all trains running in its area. Most of all communication performed by wireless in this level. However, two RBCs are not communicating with each other via GSM-R systems, but they transmit information via optical cable [6][7].

\subsection{ETCS Level 3}

ETCS Level 3 is the highest official level of the ETCS train control family. Three important features are continuous speed monitoring, radio train control and the moving block system. The communication between the track and the vehicle takes place via the GSM-R system, while the possibly only point signal transmission of the balises may only serve the purpose of positioning. RBC provides information to trains and keeps them in touch. Level 3 operates on the principle of moving block control. Each train transmits its ID, location, direction, and speed to the RBC, which performs calculations in order to maintain safe traffic and communicates train passes to the trains. The communication between the computer and the trains is continuous, so the computer always knows the current position of the trains in that areas, thus calculating and monitoring the safe track speeds. Except for the moving block subsystem, everything is the same as the Level 2 configuration [6][7].

Unfortunately, ETCS Level 3 introduction and application has not become widespread due to several train accidents [12].

\section{ETCS LEVEL 4 (plan)}

First, the basic concept is to eliminate all track-side equipment in rail transport. As a result, drivers receive all instructions and information directly via the information display on the instrument panel. The use of balises will not be necessary in the future as the GSM$\mathrm{R}$ communication system can fully replace it. It will provide location data on-board GPS transmitter to the subsystem developed for this purpose, which will further assist and simplify the work of those working in the sector through data processing and analysis. To do this, the locomotive has to be equipped with a GPS tracker with a measurement accuracy of at least 1 meter. Continuous position data can be used to extract the most important information about the transport. We can measure the elapsed time and the distance between two GPS coordinates, from which speed and other data can be calculated [14].Error! Reference source not found. At this level are RBCs also located at the larger stations, where the GSM-R communication system sends the information for further processing. ETCS Level 4 implements two-way data movement between radio block centers and locomotives via GSM-R communication system. The driver sees the instructions on the display, but the system can intervene automatically according to a given signal. The communication between two vehicles can be realized by some intelligent subsystems. This is a V2V subsystem in ETCS Level 4 namely Vehicle-to-Vehicle communication. With this subsystem, collisions between trains can be completely ruled out and any other detected traffic hazards detected can be shared [15].

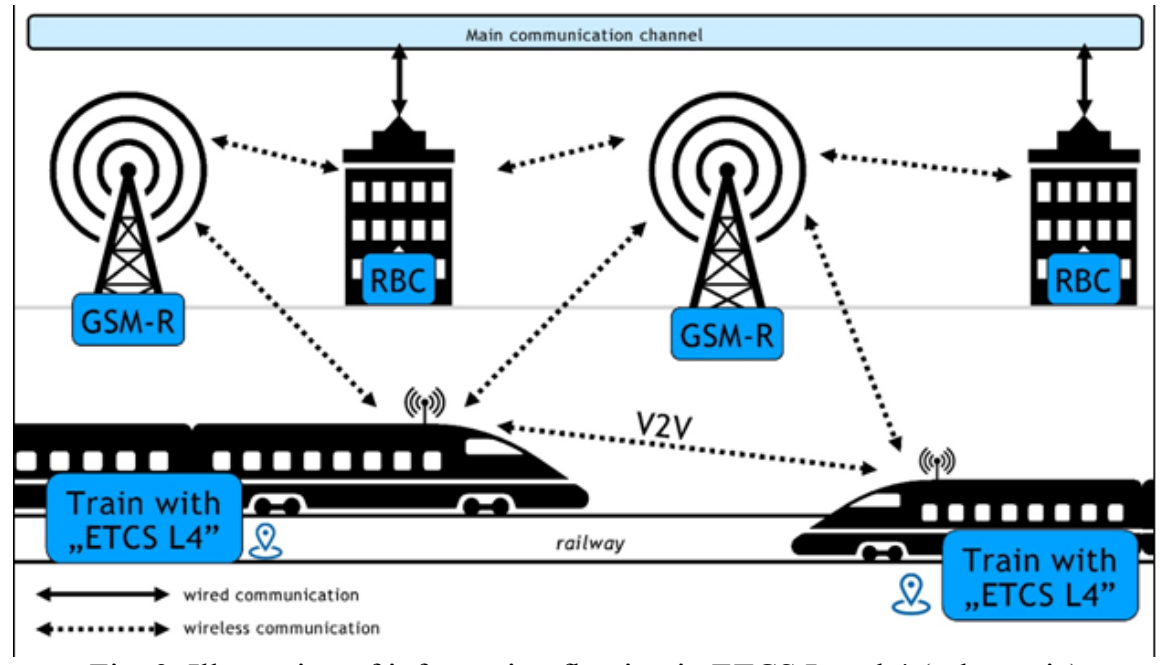

Fig. 3. Illustration of information flowing in ETCS Level 4 (schematic)

When assembling railway trains, different wagons are placed behind the locomotive. In order to know the details of the complete assembly, it is necessary to be able to identify each individual wagon and its unique characteristics. When wagons are connected, the properties coded in the unique identifier can be read. In this way, important information for the railway operation can be established.

The actual length of the train is an important safety factor, when measuring the braking distance by GPS. The train control system calculates the minimum braking distance at the current speed. Multiplying the calculated braking distance by a safety factor gives a safe braking distance. This is necessary due to extreme weather conditions and measurement inaccuracies. The $\mathrm{V} 2 \mathrm{~V}$ indicates, when a vehicle is approaching within a safe braking distance behind another vehicle. The subsystem is ideally able to reduce the speed of approaching train.

At first glance, the lack of track-side elements appears, but their function has been replaced in the locomotive with a separate display. There will be no 
need for balises, barriers, and distribution LEU cabinets to control them. If there are no track-side elements, there are no installation and operating costs. Therefore, the number of staff reserved for maintenance and operation can also be reduced. Another source of problem can be eliminated as track-side components are also exposed to extreme weather conditions and thieves. Replacing and maintaining them is very costly at the lower levels of ETCS. In case of ETCS Level 4, only GSM-R towers would be exposed to weather and vandals. A further advantage due to the modular design of ETCS is that the GSM-R communication system is required for Level 2 and Level 4. This would make Level 2 easy to upgrade to Level 4 , as $90 \%$ of the information is transmitted or received through this system. After the infrastructure of the GSM-R communication system was built, only GPS tracking needs to be installed in the locomotives. [16]. In the case of Level 2 as well, the communication took place on the GSM-R system, so when it comes to upgrading to Level 4, the on-board elements need only to be updated. Software upgrades for RBCs are also requirement in this case.

It can be concluded, that the installation of ETCS Level 4 is more costly, if it is installed on a railway, where the train control was not one of the ETCS levels, or where there was no train control at all. In this case, it is necessary to start the development from zero, but it is still less costly to deploy ETCS Level 4, than for nonstandardized train protection systems with similar track-side elements.

\section{CONCLUSION}

The operation of complex supply chains is significantly influenced by the reliability of the available transport infrastructure. In order to improve this, we examined the operation of the unified European train control system, which is already used in practice. We have identified its shortcomings and we have developed a proposal for its further development. ETCS Level 4 could efficiently serve rail transport on the modern Silk Road. The detailed elaboration of the development proposal is the subject of further research.

\section{REFERENCES}

[1] Zhang, M., Zhang, J., Cheng, T.C.E., Hua, G.Why and how do branders sell new products on flash sale platforms?, European Journal of Operational Research P. 337-351 (2018) DOI: 10.1016/j.ejor.2018.02.051

[2] Retail e-commerce sales worldwide from 2014 to 2023 - statista (2019)

https://www.statista.com/statistics/379046/worldw ide-retail-e-commerce-sales/

[3] Ismailov, Z., Kononov, D. - New silk way: Effective management of container transportations in the conditions of uncertainties, 12th International Conference "'Management of LargeScale System Development"", MLSD 2019; Moscow; DOI: 10.1109/MLSD.2019.8911058

[4] Fehér Könyv - Útiterv az egységes európai közlekedési térség megvalósításához - Úton egy versenyképes és erőforrás-hatékony közlekedési rendszer felé, Európai Bizottság, Brüsszel, 2011, $5 / 19 \mathrm{p}$.

[5] Vincze, B., Tarnai, G. - EVOUTION OF TRAIN CONTROL SYSTEMS (2020)

http://web.axelero.hu/egzo/doc/2006 zel evolutio $\underline{\text { n.pdf }}$

[6] Jóvér, B. - ETCS Az Egységes Európai Vonatbefolyásoló Rendszer, MÁV Baross Gábor Oktatási Központ 2006.

[7] Stanley, P. - ETCS for Engineers, Institution of Railway Signal Engineers 2011. (ISBN: 9783962450342)

[8] Herege, J. - Vasúti berendezések működése, MÁV Zrt. Budapest, 1973., 27/39 p.

[9] Nguyen, H.N., Cavalli, A. - Formal verification of coordination systems' requirements - A case study on the European Train Control System, Proceedings of the International Conference on Software Engineering and Knowledge Engineering, SEKE, pp. 393-396. (2014)

[10]Faber, J., Meyer, R. - Model checking datadependent real-time properties of the European train control system, Proceedings of Formal Methods in Computer Aided Design, 76-77. (2006) http://doi.org/10.1109/FMCAD.2006.21

[11]Balise http://www.railsystem.net/balise/

[12] Clark, N., Stares. J., - Trains Collide Head-On in Belgium, The NewYork Times, 2010

[13] https:/www.nytimes.com/2010/02/16/world/euro pe/16belgium.html

[14]Rudolf Á. - GPS rendszer müködése és alkalmazása a biztonságtechnikában, Hadmérnök 8(1) 40-43, (2012)

[15]Maros, D., Tokodi, D., Tiszavölgyi, Zs. - A GSM$\mathrm{R}$ rendszer jelene és jövője, Vezetékek világa 2015/1 XX. évfolyam, 1 szám. 17/21 p. Baldinia, G. An early warning system for detecting GSM-R wireless interference in the high-speed railway infrastructure, Elsevier, Róma, 141 p.

[16]Zhang, X.; Li, J.; Liu, Y.; Zhang, Z.; Wang, Z.; Luo, D.; Zhou, X.; Zhu, M.; Salman, W.; Hu, G.; Wang, C. - Design of a Fatigue Detection System for High-Speed Trains Based on Driver Vigilance Using a Wireless Wearable EEG, Sensors 2017, 486. https://doi.org/10.3390/s17030486

ACKNOWLEDGMENTS: "The described article was carried out as part of the EFOP-3.6.1-16-2016-00011 "Younger and Renewing University - Innovative Knowledge City - institutional development of the University of Miskolc aiming at intelligent specialisation" project implemented in the framework of the Szechenyi 2020 program. The realization of this project is supported by the European Union, co-financed by the European Social Fund."

Authors: László Erdei, Béla Illés, Péter Tamás, University of Miskolc, Faculty of Mechanical Engineering and Informatics, Institue of Logistics, 3515 Miskolc-Egyetemváros, Hungary

E-mail: altlaci@uni-miskolc.hu, tamas.peter@unimiskolc.hu, altilles@uni-miskolc.hu 